\title{
SOCIAL ENTREPRENEURSHIP: SOCIAL ENTERPRISES AND THEIR MARKETS IN BULGARIA
}

\author{
Venelin Terziev ${ }^{1}$ and Marin Georgiev ${ }^{2}$ \\ ${ }^{1}$ Academician of the Russian Academy of Natural History, Moscow, Russia, \\ Prof. D.Sc. (Ec.), D.Sc. (National Security), D.Sc. (Social Activities), Ph.D., National Military \\ University, Veliko Tarnovo, Bulgaria; University of Rousse, Rousse, Bulgaria, terziev@skmat.com \\ ${ }^{2}$ Ph.D., National Military University, Veliko Tarnovo, Bulgaria, clementon@abv.bg
}

\begin{abstract}
In the last decade the concept of development and promotion of social economy and social entrepreneurship are part of EU policy to tackle the social exclusion of persons in a vulnerable position. Also, the model of social economy is one of the key instruments for achieving social objectives within the framework of the sustainable and inclusive growth. Social benefits are measured by integration and employment of disadvantaged people, the contribution to the process of social inclusion of other vulnerable people, and the economic indicator is expressed by saved public funds for social welfare, on the one hand, and the additional funds compensating the social costs of long-term unemployment.
\end{abstract}

Keywords: social entrepreneurship, social enterprises, markets, health support.

\section{INTRODUCTION}

In the last decade the concept of development and promotion of social economy and social entrepreneurship are part of EU policy to tackle the social exclusion of persons in a vulnerable position. Also, the model of social economy is one of the key instruments for achieving social objectives within the framework of the sustainable and inclusive growth. Social benefits are measured by integration and employment of disadvantaged people, the contribution to the process of social inclusion of other vulnerable people, and the economic indicator is expressed by saved public funds for social welfare, on the one hand, and the additional funds compensating the social costs of long-term unemployment. What is important to happen is to create suitable conditions for the development of social enterprises with the widest possible range - vulnerable groups themselves and their problems are diverse and different, and the "answer" to their needs must be flexible in order to be efficient and effective; "way to solutions" is not important (the path may be different, as are diverse and vast opportunities for economic initiatives) that leads to the result itself, the result is important - better integration and sustainable tackling of social exclusion.

The Economic and Social Council of the Republic of Bulgaria (ESC) believes that social enterprises in Bulgaria are still an untapped business model. Current social enterprises are mainly non-governmental organizations by applying the relevant legislation creating social enterprises whose business is focused on the realization of the social purpose and mission of the organization. Social enterprises in Bulgaria operate in 
various sectors, the most serious part are in: the delivery of social services; providing jobs for people with disabilities; mediation in finding employment of unemployed persons; provision of health services; activities in the field of education and others.

In realizing these activities the leading is not the end product but the achieved social effect on individuals themselves expressed in obtaining the necessary support to integrate into society. In this sense, there are three basic models of social enterprises:

- The most common model is the one that creates jobs and develops the workforce. By business jobs are created primarily for people with disabilities. Most often the social enterprise is the employer of people with disabilities in order to achieve the integration of persons with disabilities in the labor market and create conditions for a better life.

- Another popular model of a social enterprise is the one in which the enterprise produces goods and seeks markets, also engaging with their distribution. Most often social enterprises involve persons with disabilities in the form of occupational therapy involved in the production of certain goods. Existing social enterprises in Bulgaria within this model are engaged in the manufacture of certain products by persons who are unemployed or socially excluded. The aim is to enable them to work and improve their social inclusion.

- The third existing model in Bulgaria is related to the provision of social services generally through payment of external customers, while social enterprise provides social services to its members. Payment is under contract with the state or a municipality. Within this model, services are provided to different users paid directly to social enterprise for direct service.

Implementing the strategy "Europe 2020" in Bulgaria, a National Reform Programme is developed. There are four priority areas: better infrastructure; competitive youth (reducing the share of early school leavers, increasing the number of young graduates, encouraging young scientists realization of young people in Bulgaria); better business environment (higher employment, more investment, incl. in innovation); more trust in state institutions (protection of interests of citizens and businesses, social justice and security).

\section{SOCIAL ENTERPRISES AND THEIR MARKETS}

Social enterprises in Bulgaria operate in several directions:

- Delivery of social services;

- Providing jobs for people with disabilities;

- Mediation in finding employment of unemployed persons;

- Provision of health services;

- Activity in the field of education and others.

In realizing these activities lead is not an end product, and the social impact on the people themselves expressed in this to obtain the necessary support to integrate into society.

Social service providers

One of the most outstanding areas of work of the Bulgarian social enterprises is the delivery of social services. This became possible after the conducted reforms in the social sphere in 2003 with amendments to the Social Assistance Act / SAA / and its implementing Rules. The provisions of the law regulating the circle of persons capable of being designated to provide necessary services, it is not proposed comprehensive range of subjects, and are described with the following features - the state, municipalities, Bulgarian physical persons registered under the Commerce Act and legal entities, individuals carrying out commercial activities and legal entities arising under the laws of another state - member of the European Union or another country of the European economic Area. And here the emphasis is not on the legal form of social enterprise, but on this activity is to support individuals and leads to social inclusion within the meaning of the SAA.

In pursuance of national policy in the social state delegate the performance of certain functions of the mayors of the municipalities in Bulgaria, as in turn give them the right to dispose of the funds for this by themselves means are provided and translated based on the state budget each calendar year. Mayors reserve the right to supplement designated by the state to local activities, providing them with funding by the respective municipal budget.

Bulgarian legislation expressly provides for the so called social negotiation - assigning social services financed by public funds to private providers. This is done through a competition organized by the Mayor of the municipality or the terms of negotiation involving the sole candidate. The control over the legality of the 
procedure may be exercised by administrative order in front of the customer or by court order before the Administrative Court. The law provides for the possibility provider of social services to provide these services alone against the agreed remuneration on market principles (Petkova, 2008, Petkova, 2009; Petkova Georgieva, Yanakieva, 2012; Petkova, Strateva, 2012a; Petkova, Tasheva, Petkov, 2018b-c).

The degree to achieve quality in the service appears:

- compliance with the criteria and standards set by the regulations to implement the SAA and the ordinance on criteria and standards for social services for children adopted by the Council of Ministers of the Republic of Bulgaria;

- required by law special registration to the Agency for Social Assistance /ASA/ and the State Agency for Child Protection in cases where beneficiaries of social services are children.

Specialized enterprises for people with disabilities

One of the regulations envisaged opportunities for development of social entrepreneurship is reflected in the Law for Integration of Persons with Disabilities /IPDA/. This approach of the legislator is different manifestation being placed focus on two main criteria by which to accept going concern as socially. The criteria are: introduced a requirement specialized enterprises and cooperatives of people with disabilities are registered in a particular legal form; Cooperatives should carry out activities related to the production of goods or provision of services, among employees should have a relevant share of people with disabilities.

Particular attention causes restriction of the law social enterprise occur in the form of commercial legal entity established under the Trade law or the Cooperatives Act. So now cannot exist as a joint venture, limited liability company, limited partnership, limited partnership shares and partnership, as well as cooperative. Practically more used forms are joint venture and limited liability companies and with this in mind that capital companies to clearly distinguish the amount of liability.

Another possibility for the registration of social enterprise, according to the special law is a cooperative of disabled people covered in the Cooperatives act. For its occurrence is sufficient declaration of intention at least seven individuals. IPDA does not clarify whether the very founders /members/ and how many of them should be tied to membership in the cooperative relationship.

The second requirement is that social enterprise is engaged in the production of goods or the provision of services, making it an active participant in the economy. In addition to that introduced quantitative dimensions of staff:

- Specialized enterprises and cooperatives for the blind and partially sighted persons - no less than 20 percent of the employee number;

- Specialized enterprises and cooperatives of people with hearing impairments - not less than 30 percent of the employee number;

- Specialized enterprises and cooperatives of persons with other disabilities - not less than 30 percent of the employee number.

In so set laws can conclude that the presence of the required legal form and economic criteria must be met cumulatively. To complete factual giving legal status to a union as a specialized enterprise for people with disabilities it is compulsory to fit in the Agency for Persons with Disabilities. Social enterprise registered under the IPDA, benefiting from more favorable treatment under Bulgarian legislation.

Health support

The activity of social enterprises in the field of health services is relatively limited, confined mainly to the guidance of some patients what type of health insurance rights and obligations are, and offering free-hold medical examinations, free distribution of drugs and devices not requiring specialized prescription. According to the main law in this area - Health Act, health facilities are structures of the national health care system in which medical and non-medical specialists carry out activities to maintain and strengthen citizens' health. Although satisfy some of these traits, social enterprises not having the status of a health establishment cannot provide health services and should limit their activity to that. The status of health institutions are national centers on public health issues, the National Expert Medical Commission (NEPC), health offices, opticians and pharmacies. According the Health act quality of medical care based on medical standards established under the Hospitals Act. It regulates medical institutions as separate organizational structures on a functional basis in which doctors or dentists alone or with other medical and non-medical specialists carry out diagnosis, treatment and rehabilitation of ill persons. These organizationally separate units should have the status of legal persons registered under the Trade law or the Cooperatives act. Social enterprises in the 
health sector achieve the desired social impact or limit its sphere of activity to the extent permitted, without the need for special registration under the Hospitals act or register as a separate company or a cooperative in accordance with legal requirements. Unfortunately, the Bulgarian legislator has not provided the opportunity the legal form of medical institutions to NGOs, which actually deters many organizations - social enterprises to offer integrated health and social services for vulnerable groups(Terziyev, 2019; Terziev, Bencheva, 2019a; Bencheva, Stoeva, Todorova, 2018; Bencheva, Tepavicharova, 2016; Tepavicharova, Bencheva, 2016a; Bogdanova, 2018a; Terziev, 2019b-c; Terziev, Bekiarova, Georgiev, 2019d; Bencheva, Stoeva, 2019e; Stoeva, 2016b-c; Arabska, 2016d; Ovcharova, 2017-a).

\section{CONCLUSION}

Social entrepreneurship is one of the most innovative ways to achieve a better quality of life, independence and inclusion in society of persons from vulnerable groups. Need to be taken key legislative changes in order set in strategic and political national documents measures to become real mechanisms to support social entrepreneurship in Bulgaria, as well as the successful development of social enterprises, requires the creation of sustainable partnerships between business, NGOs and the public sector - partnerships in which each of these actors recognizes its role to achieve socially important objectives and is willing to invest resources in that(Terziev, Nichev, Georgiev, 2019f-g).

This report provides an analysis of the development of social entrepreneurship in Bulgaria according to: International project Social enterprise skills for business advisors - SESBA of the European program for education, training, youth and sport "Erasmus +", Grant Agreement №2015-1-EL01-KA202-014097 (20152018).

\section{REFERENCE LIST}

Terziyev, Venelin. (2019). Sotsial'naya ekonomika i sotsial'noye predprinimatel'stvo. // Sovremennyy menedzhment: problemy i perspektivy: sbornik statey po itogam XIV mezhdunarodnoy nauchnoprakticheskoy konferentsii „Sovremennyy menedzhment: problemy i perspektivy“ 25-26 aprelya 2019 goda, Ministerstvo nauki i vysshego obrazovaniya Rossiyskoy federatsii, Izdatel'stvo SanktPeterburgskogo gosudarstvennogo ekonomicheskogo universiteta, Sankt-Peterburg, Rossiya, 2019 s. 412-435, ISBN 978-5-7310-4567-4 (Терзиев, Венелин. Социальная экономика и социальное предпринимательство. // Современный менеджмент: проблемы и перспективы: сборник статей по итогам XIV международной научно-практической конференции „Современный менеджмент: проблемы и перспективы“ 25-26 апреля 2019 года, Министерство науки и высшего образования Российской федерации, Издательство Санкт-Петербургского государственного экономического университета, Санкт-Петербург, Россия, 2019, с. 412-435, ISBN 978-5-7310-4567-4).

Terziev, V, Bencheva, N. (2019a). Current status of social entrepreneurship in Bulgaria. // Advances in Bulgarian science'2018, National centre for information and documentation (NACID), Sofia, 2019, pp.5-18, ISSN 1314-3565.

Bencheva, N., Stoeva, T., Todorova, S. (2018). Key Skills and Competences for Social Business Advisors: Views from Experts, International Journal of Organizational Leadership, 7(2018), pp.413-425; ISSN 2383-1103 (Print); ISSN 2345-6744 (Online).

Bencheva, N., Tepavicharova, M. (2016). Support structures for social entrepreneurship in Bulgaria, The first scientific conference on social entrepreneurship on "Tips, skills and tools for consulting social entrepreneurs", pp.29-35, ISBN 978-954-517-249-6 ISBN 978-954-517-250-2.

Tepavicharova, M., Bencheva, N. (2016a), Factors for development of the educational and professional qualitication profile of the managers from the services sector in Bulgaria, Scientific journal «Economics and Finance», Science and Practice, Conference proceedings, Citation Index - Social Sciences \& Humanities (CPCI-SSH), Thorpe-Bowker, Melbourne, Australia, pp.42-47, ISBN 978-0-9942661-3-2.

Petkova, St., (2008). Balanced scorecard as instrument of strategic controlling, Forum Gesundheit und Soziales, Beitrage aus Lehre, Forschung und Praxis der Studiengange der Evangelischen Fachhochschule Berlin, Heft 6, p.60-68, ISSN 1863-1851, Berlin, 2008.

Petkova, St. (2009). Tendentsii za upravlyavane na strategicheskiya risk s pomoshtta na balansirani sistemi ot pokazateli, Godishnik na MGU „Sveti Ivan Rilski”, tom 52, str.87-91, ISSN 1312-1820, Sofiya, 2009 (Петкова, Ст., Тенденции за управляване на стратегическия риск с помощта на балансирани 
системи от показатели, Годишник на МГУ „Свети Иван Рилски”, том 52, стр.87-91, ISSN 13121820, София, 2009).

Petkova - Georgieva, St., A., Yanakieva, (2012). Balansiranata sistema ot pokazateli kato savremenen metod na upravlenie $v$ turisticheskoto predpriyatie, akademichno spisanie "Upravlenie i obrazovanie", tom VIII, kn. 1, str.140-144, ISSN 13126121, Burgas, 2012. (Петкова - Георгиева, Ст., А., Янакиева, Балансираната система от показатели като съвременен метод на управление в туристическото предприятие, академично списание "Управление и образование”, том VIII, кн. 1, стр.140-144, ISSN 13126121, Бургас, 2012).

Petkova, St., Iv. Strateva, (2012a). Opredelyaneto na strategicheskite vrazki po deynosti kato klyuchov podhod v kontrolinga, godishnik na Universitet "Prof. d-r Asen Zlatarov", Br. XLI, kn. 2, str.106-112, ISSN 1312-1359, Burgas, 2012 (Петкова, Ст., Ив. Стратева, Определянето на стратегическите връзки по дейности като ключов подход в контролинга, годишник на Университет “Проф. д-р Асен Златаров", Бр. XLI, кн. 2, стр.106-112, ISSN 1312-1359, Бургас, 2012).

Bogdanova, Margarita. (2018a). Policies and Instruments for Social Development. Journal of Innovations and Sustainability, Plovdiv, Bulgaria, 4, 2018, 1, pp. 59-63, ISSN 2367-8127 (CD-ROM), ISSN 23678151 (ON-LINE).

Petkova, S., Tasheva, Y., P. Petkov, (2018b). Assessment of the Pyrolytic Fractions from Refused - Derived Fuel, Oxidation Communications, p. 462 - 467, book 41, vol. 3, ISSN 0209-4541, 2018.

Petkova, S., Tasheva, Y., P. Petkov, (2018c). Evaluation of Possibility to Use Liquid Pyrolysis Fractions as Fuel, Oxidation Communications, p. 468 - 474, book 41, vol. 3, ISSN 0209-4541, 2018.

Terziev, Venelin. (2019b). Social policy and labor market development in Bulgarian transition period. INTCESS 2019- 6th International Conference on Education and Social Sciences, 4-6 February, 2019, Dubai, International Organization Center of Academic Research, 2019, pp. 703-714, ISBN: 978-60582433-5-4

Terziev, Venelin. (2019c). Theoretical basis of development of labor market and social policy in the republic of Bulgaria. INTCESS 2019- 6th International Conference on Education and Social Sciences, 4-6 February, 2019, Dubai, International Organization Center of Academic Research, 2019, pp. 715-726, ISBN: 978-605-82433-5-4.

Terziev, V., Bekiarova, N., Georgiev, M. (2019d). Support structures for the development of social entrepreneurship. // KNOWLEDGE - Capital of the future, International Journal Scientific Papers Vol. 29.1, February, 2019, Institute of knowledge management - Skopje, Macedonia, 29, 2019, N 1, pp. 21-25, ISSN 1857-923X (for e-version), ISSN 2545 - 4439 (for printed version).

Bencheva, N., Stoeva, T. (2019e). The role of management skills in social entrepreneurship: expert assessment. // 20th International conference - Knowledge without borders, Vrnjacka Banja, Serbia (29-31.03.2019), Institute of knowledge management - Skopje, Macedonia, 30, 2019, N 6, pp. 15931597, ISSN 1857-923X (for e-version), ISSN 2545 - 4439 (for printed version).

Stoeva, Teodora. (2016b). Predizvikatelstva i potrebnosti ot obucheniya na sotsialnite biznes konsultanti. // Parva nauchna konferentsiya po sotsialno predpriemachestvo. Saveti, umeniya i instrumenti za konsultirane na sotsialnite predpriemachi. Agraren Universitet Plovdiv, 2016, str. 71-74 (Стоева, Теодора. Предизвикателства и потребности от обучения на социалните бизнес консултанти. // Първа научна конференция по социално предприемачество. Съвети, умения и инструменти за консултиране на социалните предприемачи. Аграрен Университет Пловдив, 2016, стр. 71-74).

Stoeva, Teodora. (2016c). Sotsialni deynosti v obshtina Plovdiv. // Parva nauchna konferentsiya po sotsialno predpriemachestvo. Saveti, umeniya i instrumenti za konsultirane na sotsialnite predpriemachi. Agraren Universitet Plovdiv, 2016, str. 111-117 (Стоева, Теодора. Социални дейности в община Пловдив. // Първа научна конференция по социално предприемачество. Съвети, умения и инструменти за консултиране на социалните предприемачи. Аграрен Университет Пловдив, 2016, стр. 111-117).

Arabska, Ekaterina. (2016d). Iziskvaniya za umeniya ot konsultantite za osiguryavane na efektivna podkrepa na sotsialnite predpriyatiya. // Parva nauchna konferentsiya po sotsialno predpriemachestvo. Saveti, umeniya i instrumenti za konsultirane na sotsialnite predpriemachi. Agraren Universitet Plovdiv, 2016, str. 75-81 (Арабска, Екатерина. Изисквания за умения от консултантите за осигуряване на ефективна подкрепа на социалните предприятия. // Първа научна конференция по социално предприемачество. Съвети, умения и инструменти за консултиране на социалните 
предприемачи. Аграрен университет Пловдив, 2016, стр. 75-81).

Ovcharova, S. (2017). Motivation in knowledge economy. // 6th International congress Knowledge Economy \& Management, 26-28.12.2007, Istanbul, Turkey, 2017, pp.1643-1651. ISSN: 1308-3937.

Ovcharova, S. (2017a). Knowledge management in some Bulgarian organizations. // 6th International congress Knowledge Economy \& Management, 26-28. 12.2007, Istanbul, Turkey, 2017, pp.19081915. ISSN 1308-3937.

Terziev, V., Nichev, N., Georgiev, M. (2019f). Current status of social entrepreneurship: social enterprises and state. // 20th International conference - Knowledge without borders, Vrnjacka Banja, Serbia (2931.03.2019), Institute of knowledge management - Skopje, Macedonia, 30, 2019, N 6, pp. 1587-1591, ISSN 1857-923X (for e-version), ISSN 2545 - 4439 (for printed version).

Terziev, V., Nichev, N., Georgiev, M. (2019g). Social enterprises and their impact in Bulgaria. // 20th International conference - Knowledge without borders, Vrnjacka Banja, Serbia (29-31.03.2019), Institute of knowledge management - Skopje, Macedonia, 30, 2019, N 6, pp. 1645-1649, ISSN 1857923X (for e-version), ISSN 2545 - 4439 (for printed version). 